\section{P32 LIVER MOBILISATION DURING LIVER RESECTION INDUCES IMMEDIATE AND PROFOUND HEPATOCELLULAR DAMAGE AND INFLAMMATION IN HUMANS}

doi:10.1136/gutjnl-2011-300857a.32

${ }^{1} \mathrm{M}$ A J van den Broek, ${ }^{2} \mathrm{R}$ Shiri-Sverdlov, ${ }^{1} \mathrm{~J} \mathrm{~J}$ W Schreurs, ${ }^{1} \mathrm{~J}$ G Bloemen, ${ }^{2} \mathrm{~V}$ Bieghs, ${ }^{1}$ W A Buurman, ${ }^{1} \mathrm{C}$ H C Dejong, 'S W M Olde Damink. 'Department of General Surgery, Maastricht University, Maastricht, the Netherlands; ${ }^{2}$ Department of Molecular Genetics, Maastricht University, Maastricht, the Netherlands

Introduction In a recent study we coincidentally showed that mobilisation of the liver was a major cause of liver surgery-induced damage. The magnitude of and mechanisms by which this damage occurs are unknown.

Aim (A) To determine the relative contribution of mobilisation during liver surgery to liver damage and (B) To examine whether there is an association between mobilisation-induced liver damage and liver inflammation.

Method Consecutive patients undergoing liver surgery requiring full mobilisation of the right hemi-liver were included. Plasma samples and liver biopsies were obtained immediately after induction, prior to and directly after liver mobilisation, and after liver transection. Liver Fatty Acid Binding Protein (L-FABP) and alanine aminotranferase (ALAT) were analysed as markers of hepatocyte injury. Specimens were stained by immunohistochemistry for myeloperoxidase (MPO), human neutrophil peptide (HNP), and caspase-3mediated cleavage generated neo-epitope of CK18 (M30). Gene expression of interleukin (IL) $1 \beta, 6$ and 8, and intercellular adhesion molecule (ICAM) were analysed by q-RT-PCR

Results Nineteen patients were included (11M/8F, median age 64 years [30-79]) who underwent major liver surgery. L-FABP levels increased significantly during liver mobilisation (from $91.7 \mathrm{ng} / \mathrm{ml}$ $[11.4-2212.5 \mathrm{ng} / \mathrm{ml}]$ to $1014.4 \mathrm{ng} / \mathrm{ml} \quad[141.4-8986.1 \mathrm{ng} / \mathrm{ml}]$, $\mathrm{p}<0.001)$ and did not increase significantly thereafter $(1315.2 \mathrm{ng} / \mathrm{ml}$ $[67.0-20099.2 \mathrm{ng} / \mathrm{ml}], \mathrm{p}=0.75)$. L-FABP levels after $\geq 60 \mathrm{~min}$ mobilisation time were significantly higher when compared to $\geq 60$ min mobilisation $(1679.7 \mathrm{ng} / \mathrm{ml}$ vs $645.9 \mathrm{ng} / \mathrm{ml}, \mathrm{p}=0.04$ ). ALAT levels increased significantly from $26 \mathrm{IU} / \mathrm{l}$ [13-147] before to $130 \mathrm{IU} / 1$ [74-813] after liver mobilisation and to $275 \mathrm{IU} / 1$ [13-1352] after transection (all $\mathrm{p}<0.05$ ). Liver mobilisation increased the numbers of positive cells in staining for MPO $(p=0.0007)$, HNP $(p=0.03)$, and M30 $(p=0.01)$, whereas transaction led to no further increase thereafter. Liver mobilisation increased the gene expression of IL1b $(p=0.01)$, IL- $6(p=0.08)$, IL-8 $(p=0.02)$ and ICAM $(p=0.007)$. Expression increases ranged from 2.8-fold in ICAM to 130-fold in IL-6. After transection, mRNA levels increased even further in IL-6 $(p=0.004)$, IL-8 $(p=0.0004)$ and ICAM $(p=0.02)$, but not IL1b $(\mathrm{p}=0.32)$

Conclusion Mobilisation of the liver during surgery induces profound hepatocellular damage and inflammation, which is associated with activation and/or infiltration of immune cells. Given the short half-life of L-FABP (14 min), hepatocyte damage predominantly occurred during mobilisation of the liver and not during transaction. These data produce insight into the mechanisms of mobilisation-induced liver damage, and provide indications for designing interventions aiming at prevention of surgery-induced liver damage in the future.

\section{P33 SERUM TOTAL CORTISOL AND PLASMA FREE CORTISOL RESPONSE AFTER LOW DOSE SHORT SYNACTHEN TEST IN STABLE CIRRHOSIS}

doi:10.1136/gutjnl-2011-300857a.33

${ }^{1} \mathrm{G}$ Fede, ${ }^{1} \mathrm{~L}$ Spadaro, ${ }^{1} \mathrm{~T}$ Tomaselli, ${ }^{1} \mathrm{G}$ Privitera, ${ }^{1} \mathrm{R}$ Scicali, ${ }^{2} \mathrm{P}$ Vasianopoulou, ${ }^{3} \mathrm{~N}$ Martin, ${ }^{3} \mathrm{M}$ Thomas, ${ }^{1} \mathrm{~F}$ Purrello, ${ }^{2} \mathrm{~A}$ K Burroughs. ${ }^{1}$ Department of Internal Medicine,
University of Catania, Garibaldi Hospital, Catania, Italy; ${ }^{2}$ The Royal Free Sheila Sherlock Liver Centre and University Department of Surgery-University College London and Royal Free Hospital, London, UK; ${ }^{3}$ Department of Clinical Biochemistry-Royal Free Hospital, London, UK

Introduction Adrenal Insufficiency (AI) defined by low dose short synacthen test (LDSST) in stable cirrhosis is frequent using serum total cortisol (TC). However no published data exist on directly measured plasma free cortisol (FC) after LDSST.

Aim We prospectively assessed adrenal insufficiency defined by LDSST in stable cirrhosis using TC and FC.

Method Patients with stable cirrhosis without shock and/or sepsis were prospectively studied using the LDSST. AI was defined by a peak-TC $<494 \mathrm{mmol} / \mathrm{l}$ (Criterion 1) and a peak-FC $<33 \mathrm{nmol} /$ (Criterion 2) $30 \mathrm{~min}$ after injection of $1 \mu \mathrm{g}$ of tetracosactrin (Synacthen).

Results 78 consecutive patients with cirrhosis were studied (Viral 16, Alcoholic: 41; other: 21). Basal TC (365 $\pm 192 \mathrm{mmol} / \mathrm{l})$ and peak TC $(571 \pm 216 \mathrm{mmol} / \mathrm{l})$ were significantly related to basal FC $(26 \pm 24 \mathrm{nmol} / \mathrm{l})$ and peak FC $(53 \pm 34 \mathrm{nmol} / \mathrm{l})$ respectively: for baseline values $R=0.78, p<0.001$, and for peak values $R=0.70$, $\mathrm{p}<0.05$. Similar results were found considering only patients with hypoalbuminemia (albumin $<25 \mathrm{~g} / 1,7$ patients): for basal value $\mathrm{R}=0.88, \mathrm{p}<0.001$; for peak value $\mathrm{R}=0.89, \mathrm{p}<0.05$. Prevalence of $\mathrm{AI}$ was $35 \%(27 / 78)$ using total cortisol (Criterion 1$)$ and $28 \%(22 / 78)$ using free cortisol (Criterion 2). There was agreement between total cortisol (Criterion 1) and free cortisol (Criterion 2) in 63 tests, in 10 AI was diagnosed only according TC (Criterion 1), and in 5 only according FC (Criterion 2 ): $\kappa$-coefficient $0.56, \mathrm{p}<0.05$. In the group with discordant tests patients had more advanced liver disease (Child score: $9.17 \pm 2.2$ vs $7.66 \pm 1.9, p=0.03$ ), lower basal TC $(237 \pm 104$ vs $395 \pm 196 \mathrm{mmol} / 1, \mathrm{p}=0.03)$, and peak TC (464 $\pm 121 \mathrm{vs}$ $597 \pm 226 \mathrm{mmol} / \mathrm{l}, \mathrm{p}=0.009$ ).

Conclusion AI defined by LDSST is frequent in stable patients with cirrhosis, using both total cortisol and free cortisol criteria. However in patients with more advanced liver disease and/or low total cortisol level, discrepancy exists between the rates of diagnosis of AI using the total and free cortisol criteria. Thus in these patients AI should be confirmed by free cortisol measurement.

\section{P34 NO EFFECT OF TENOFOVIR OR ENTECAVIR ON VITAMIN D LEVELS IN CHRONIC HEPATITIS B MONO-INFECTED PATIENTS. SINGLE CENTRE 'REAL LIFE' COHORT EXPERIENCE}

doi:10.1136/gutjn-2011-300857a.34

${ }^{1} \mathrm{H}-\mathrm{L}$ Nguyen, ${ }^{1} \mathrm{I}$ Carey, ${ }^{1} \mathrm{M}$ A B Al-Freah, ${ }^{1} \mathrm{D}$ Joe, ${ }^{2} \mathrm{R}$ Sherwood, ${ }^{1} \mathrm{~S}$ Knighton, ${ }^{1} \mathrm{P}$ Harrison, ${ }^{1} \mathrm{~A}$ Suddle, ${ }^{1} \mathrm{~K}$ Agarwal. ${ }^{1}$ Institute of Liver Studies, King's College Hospital, London, UK; ${ }^{2}$ Clinical Biochemistry, King's College Hospital, London, UK

Introduction Increasing evidence confirms the pivotal role of Vitamin $\mathrm{D}$ in immunomodulatory and metabolic processes. Vitamin D deficiency has an impact on long-term health outcomes. Data from HIV populations demonstrate negative effects of Tenofovir (TDF) on vitamin $\mathrm{D}(\mathrm{VD})$ levels and bone mineral density.

Aim To determine the impact of TDF on VD levels, with calcium and phosphate in patients mono-infected with HBV.

Method Retrospective study of all patients treated with TDF. VD $(\mu \mathrm{g} / \mathrm{l})$, phosphate $\left(\mathrm{PO}_{4}, \mathrm{mmol} / \mathrm{l}\right)$, calcium $\left(\mathrm{Ca}^{2+}, \mathrm{mmol} / \mathrm{l}\right)$ and alkaline phosphatase (ALP, IU/l) were checked at baseline, and 12 months after TDF or Entecavir (ETV) exposure.

Results Patients with complete data were analysed ( $n=313), 22$ patients were excluded because of combination treatment TDF and 